\title{
Analysis of knowledge regarding Biliary Atresia among healthcare providers and laypersons in East Jakarta after educational intervention
}

\author{
Hanna Lianti \\ Faculty of Medicine, Universitas Indonesia, Indonesia, hannalianti13@gmail.com \\ Novi Kurnia \\ Faculty of Medicine, Universitas Indonesia, Indonesia, nk.cendrawan@gmail.com
}

See next page for additional authors

Follow this and additional works at: https://scholarhub.ui.ac.id/ajce

Part of the Public Health Education and Promotion Commons

\section{Recommended Citation}

Lianti, Hanna; Kurnia, Novi; Rinaldhy, Kshetra; Aji, Amanda Safira; Ismet, M Febriadi; and Amaliah, Rizky (2020). Analysis of knowledge regarding Biliary Atresia among healthcare providers and laypersons in East Jakarta after educational intervention. ASEAN Journal of Community Engagement, 4(1).

Available at: https://doi.org/10.7454/ajce.v4i1.1053

Creative Commons License

\section{(c) (i) ()}

This work is licensed under a Creative Commons Attribution-Share Alike 4.0 License.

This Case-Based Article is brought to you for free and open access by the Universitas Indonesia at ASEAN Journal of Community Engagement. It has been accepted for inclusion in ASEAN Journal of Community Engagement. 


\title{
Analysis of knowledge regarding Biliary Atresia among healthcare
} providers and laypersons in East Jakarta after educational

\section{intervention}

\author{
Hanna Liantia, Novi Kurniaa, Kshetra Rinaldhya*, Amanda Safira Ajia, M. \\ Febriadi Ismet ${ }^{a}$, Rizky Amaliah ${ }^{a}$ \\ ${ }^{a}$ Faculty of Medicine, Universitas Indonesia, Indonesia
}

Received: December $2^{\text {nd }}, 2019||$ Revised: April 24 $4^{\text {th }} \&$ July $5^{\text {th }}, 2020||$ Accepted: July $26^{\text {th }}, 2020$

\begin{abstract}
Biliary atresia (BA) is the most common cause of death due to liver disease in children and is the most common indication for pediatric liver transplantation. The success rate of the management of BA is very dependent on the age of the patient at the time of surgery. However, patients with BA were often diagnosed late because of the lack of parents' and primary healthcare providers' knowledge regarding BA. This study aims to evaluate the effectiveness of health education in improving the knowledge of healthcare providers and laypersons. A total of 371 respondents participated in this pre-post study with no control group, consisting of 234 laypersons (community health workers, new mothers, and expectant mothers) and 137 healthcare providers (medical doctors, midwives, and nurses). There were significant increases in the median values between pretest and posttest knowledge scores in both the healthcare provider and layperson groups $(p<.05)$. Health education was effective in increasing public knowledge about BA.
\end{abstract}

Keywords: Biliary Atresia; health education; laypersons; neonatal jaundice; educational intervention.

\section{Introduction}

Biliary atresia (BA) is a rare childhood disease in which there is a blockage of bile flow caused by an abnormally narrow, blocked, or absent extrahepatic biliary tract. BA is characterized by symptoms of cholestasis, with jaundice, pale yellow stool, and dark urine. The symptoms of BA are initially indistinguishable from other causes of neonatal jaundice. However, unlike those of physiological causes, the symptoms in BA continue to worsen and persist two weeks after birth. The general condition of a child with BA is initially good. Later, when liver failure develops, the patient begins to exhibit weight loss, increased abdominal circumference due to ascites and splenomegaly, and bleeding diathesis due to impaired vitamin $\mathrm{K}$ absorption. If left untreated, this condition will lead to cirrhosis and death. (Averbukh \& Wu, 2018; Hartley, Davenport, \& Kelly, 2009; Sanchez-Valle, 2017)

\footnotetext{
*Correspondence Author: kshetra@ui.ac.id
} 
Hanna Lianti, Novi Kurnia, Kshetra Rinaldhy, Amanda Safira Aji, M. Febriadi Ismet, Rizky Amaliah | ASEAN Journal of Community Engagement | Volume 4, Number 1, 2020

BA is found in about 0.5 to 0.8 per 10,000 live births. Around the world, the reported incidence varies, from 1 per 19,000 live births in Caucasians to 1 per 5500 in Asians and Pacific Islanders. In Indonesia, no official data on the incidence of BA has been published. The population of Indonesia was 237.6 million, according to the 2010 national census. Based on the World Bank 2015 data, the Indonesian birth rate was 20 per 1000 people. (United Nations, 2019) According to these data, if we estimate the incidence of BA in about 1 per 10,000 live births, around 480 babies will have BA per year in Indonesia. Data from Dr. Cipto Mangunkusumo Hospital, Jakarta, Indonesia (Rumah Sakit Umum Pusat Nasional Dr. Cipto Mangunkusumo/RSCM) showed that during the period from January 2011 to December 2017, 83 patients were referred to the center with end-stage liver disease due to BA. (Oswari, 2017) There were presumably more patients who succumbed to the disease before they could be successfully referred to our center.

Although BA is a rare disease, it is the most common cause of death from liver disease in infants. It is also the most common indication for pediatric liver transplantation. (Anderson et al., 2008; Morinville et al., 2016) Without treatment, patients with BA will experience progressive liver failure leading to death within two years. (Bassett \& Murray, 2008) At the moment, the main management of BA consists of a hepatoportoenterostomy (HPE), also known as the Kasai procedure, which aims to restore bile flow. One of the keys to the success of the Kasai procedure is the patient's age at the time of surgery. Surgery performed by 90 days old will significantly reduce the success rate of the Kasai procedure. (Nio et al., 2010; Nio, Wada, Sasaki, \& Tanaka, 2015) Cirrhosis and end-stage liver disease, major morbidity resulting from untreated BA, requires very costly liver transplantation as the ultimate therapy. This morbidity may be avoided by diagnosing BA and referring the patient for the Kasai procedure early before the patient is older than three months of age.

A delay in the detection of BA is the most common problem in its management. A delay in diagnosing BA is not only a significant problem in our country but also in other countries. In India, only $20 \%$ of cases that present in most centers were aged less than 60 days. (Narasimhan et al., 2001) The same figure was found in our center. Based on data from the Hepatology Division of Department of Pediatrics at RSCM from 1998 to 2009 , only $20 \%$ of patients aged less than two months were successfully referred to our center. (Oswari, 2017) 
Hanna Lianti, Novi Kurnia, Kshetra Rinaldhy, Amanda Safira Aji, M. Febriadi Ismet, Rizky Amaliah | ASEAN Journal of Community Engagement | Volume 4, Number 1, 2020

This high percentage of delayed diagnosis is thought to be caused by a lack of knowledge and awareness regarding BA among parents and primary healthcare providers. (Campion et al., 2001) Besides being a very rare disease, the symptoms of BA are similar to other causes of neonatal cholestasis, such as physiological neonatal jaundice. (Averbukh \& Wu, 2018) Nearly half of all newborn infants exhibit jaundice in the early days of life, making a diagnosis other than physiologic jaundice or associated breast milk jaundice extremely challenging. (Wang, 2015) As physiological jaundice will improve by exposing an infant to UV light and differentiating between physiologic and pathologic jaundice is difficult, infants with pathologic jaundice often will be exposed to sunlight for weeks to months, even when there was no improvement. This may be caused by parents' lack of knowledge; in this case, the delay in diagnosis is categorized as a patient delay. At other times, parents may have been more suspicious and did bring their child to be evaluated at their nearest medical center. However, because of the medical personnel's lack of knowledge, the infant may not get the proper care and early referral. This is called a doctor's delay. Therefore, a high index of suspicion is key to early diagnosis. (Wildhaber, 2012)

It is necessary to increase the awareness of parents and healthcare providers concerning BA to improve the rate of early detection and outcomes of the Kasai procedure performed, and reduce the need for costly liver transplantation. (Kelly, 2017; Ramachandran, Safwan, Reddy, \& Rela, 2015) We aim to increase healthcare providers' and laypersons' awareness by conducting an educational seminar and workshop on BA, especially on the early detection of BA. The intervention was constructed in this way, according to Edgar Dale's Cone of Learning, where it is stated that active learning in the form of simulating the real experience will make the participants retain at least $90 \%$ of the knowledge learned. (Davis \& Summers, 2015; Lee \& Reeves, 2018) Role-play induced the development of communication skills and active listening and resulted in the learners' enthusiasm and motivation. (Vizeshfar, Zare, \& Keshtkaran, 2019) Participants were expected to be educators as well as health promoters for their community, and to be able to teach and motivate new parents to monitor their children's stool to detect BA early. Health education supports the creation of conditions for change, the growth competence of individuals and groups in an independent action for health at different levels of the organization of social life. (Przybylska, Borzęcki, Drop, Przybylski, \& Drop, 2014) 
Hanna Lianti, Novi Kurnia, Kshetra Rinaldhy, Amanda Safira Aji, M. Febriadi Ismet, Rizky Amaliah | ASEAN Journal of Community Engagement | Volume 4, Number 1, 2020

As a disease with high morbidity and high cost, BA warrants screening. This study introduced the use of the Stool Color Card (SCC) as a beneficial screening tool. The SCC showed the color spectrum of a baby's stool from acholic pale stool to normal stool. It is an objective tool that helps parents and clinicians to recognize discolored infant stools reliably. (Witt et al., 2015) The SCC method was introduced in 1994 in Tochigi Prefecture, Japan. This concept was first implemented nationwide in Taiwan in 2004, followed by a nationwide screening in Japan in 2012. (Matsui, 2017) The SCC method has been studied in several countries and has been proven to reduce the number of delays in the diagnosis of BA. (Gu et al., 2015; Hsiao et al., 2008; Kong et al., 2016; Lien et al., 2011; Tseng, Lai, Lin, \& Fu, 2011) A nationwide cohort study in Taiwan showed that following the implementation of the SCC, the rates of early (within 60 days) Kasai procedure improved and led to a significant reduction in the hospitalization rate and mortality rate (Lee et al., 2016).

A large scale American study concluded that screening with the SCC is an effective, low-cost strategy and will help reduce costs in the treatment of BA. (Mogul et al., 2015) The American Academy of Pediatrics advocated for the implementation of newborn screening for BA even in the United States, a low incidence country. (Goodhue, Fenlon, \& Wang, 2017) Screening with the SCC seemed to increase parents' and healthcare providers' awareness of BA and, in turn, reduced proportions of late referral. Screening might be especially useful in areas with a high proportion of late referrals. However, in Indonesia, the SCC has not been used. This study will also act as a pilot study for the use of SCC in Indonesia. Further evaluation and development would be needed to adapt the use of the SCC in Indonesia.

This study aims to evaluate the effect of health education as an intervention for healthcare providers' and laypersons' level of knowledge concerning BA. The purpose of this research that pertains to community engagement is to evaluate how health education may empower laypersons to be active participants in health care, specifically in the early diagnosis of BA. 


\section{Methods}

\subsection{Study population}

This study was conducted at four primary healthcare centers affiliated with RSCM in East Jakarta, namely the primary healthcare centers of Ciracas, Pulo Gadung, Pasar Rebo, and Kramat Jati Sub-districts during the period from August to September 2019. Before the study, a permit was obtained from the East Jakarta District Health Office. All four primary healthcare centers agreed to participate in the study. These primary healthcare centers invited their respective community health workers who were spread across their districts to participate in this study. Every sub-district had three to five community healthcare workers. One or two individuals from each sub-district were randomly selected to participate in the study. These primary healthcare centers also coordinated with their respective mother and childcare clinics (poliklinik Kesehatan Ibu dan Anak) to ensure that new mothers and expectant mothers also attended the proposed health education event.

All healthcare providers who worked in these primary healthcare centers were involved in the study. All healthcare providers and laypersons who were present at the time of the interventional health education were included in the sample. Using the total sampling method, a sample of 371 people was obtained. A total of 234 laypersons (community health workers, mothers, and expectant mothers), and 137 healthcare providers (doctors, nurses, and midwives) agreed to participate in the study.

\subsection{Study design}

This research is a quasi-experimental study without a control group and with a pretest and posttest design, using a self-administered questionnaire.

\subsection{Intervention}

The interventional health education in this study was performed by medical specialists and consultants from the Division of Pediatric Surgery of the Department of Surgery, RSCM. Two consultant pediatric surgeons developed the lecture. The same consultants also acted as educators who gave seminars for all four primary healthcare centers. The health education intervention developed by the investigators in this study was delivered as lecture seminars, discussions, and workshops. The participants were 
Hanna Lianti, Novi Kurnia, Kshetra Rinaldhy, Amanda Safira Aji, M. Febriadi Ismet, Rizky Amaliah | ASEAN Journal of Community Engagement | Volume 4, Number 1, 2020

first administered a pretest questionnaire to evaluate their initial level of knowledge about BA. Afterward, a lecture was given on the topic of BA with an emphasis on how to detect patients suspected of having BA. The participants were then provided prompts for discussion. They were allowed time to do a dramatic presentation that simulated the real experience of facing a jaundiced baby with BA as the potential diagnosis. The simulation was focused on how to differentiate between physiological and abnormal jaundice, especially that due to BA, in a child. Another focus of the simulation was how to detect BA early using a simple screening tool; in this case, the SCC. At the end of the simulation, participants were given the posttest questionnaire. The entire intervention lasted a total duration of 1.5-2 hours.

Participants were also given an SCC to be used in the workshop and distributed to new parents at their respective healthcare centers. The SCC [Figure 1] is a card that shows the color spectrum of a baby's stool, ranging from pale or acholic (abnormal) to normal. The sample is numbered 1-7 for objective assessment, with the sample numbers 1-3 showing the color spectrum of acholic stool, whereas sample numbers 4-7 showing the color variants of normal stool. Participants were educated to compare the color of a baby's stool with the color listed on the SCC. The number that corresponds to the color of the baby's stool should be written on the card, and evaluated every week, from birth to the age of eight weeks. If within eight weeks, the baby's stool showed any abnormality, the baby should be brought immediately to a healthcare provider for evaluation instead of waiting until the eight weeks are over and the SSC is completed. 
Hanna Lianti, Novi Kurnia, Kshetra Rinaldhy, Amanda Safira Aji, M. Febriadi Ismet, Rizky Amaliah | ASEAN Journal of Community Engagement | Volume 4, Number 1, 2020

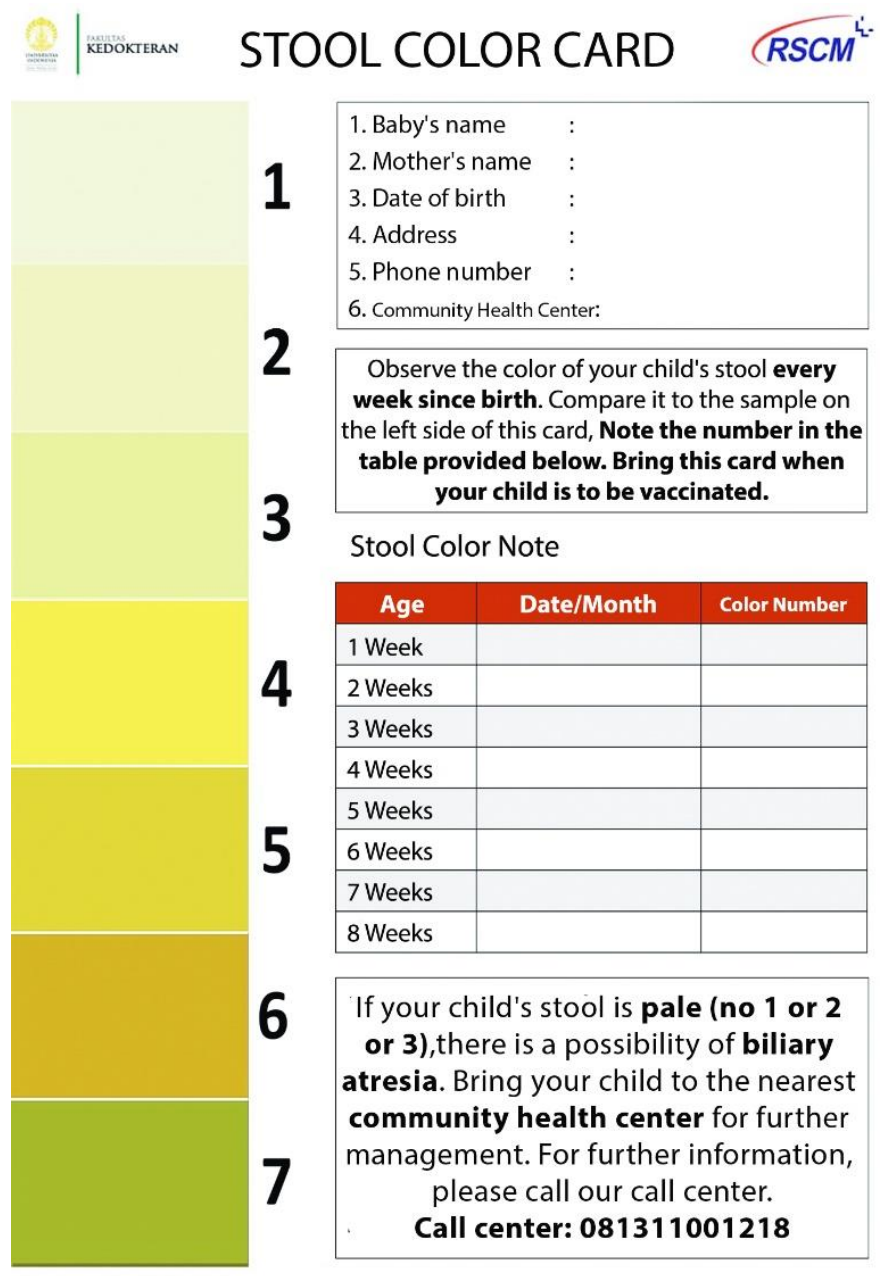

Fg. 1. Stool Color Card

Source: Adapted from: Japanese Stool Color Card (Japanese Organization for International Cooperation in Family Planning, 2019)

\subsection{Data collection procedures}

Participants were given a pretest questionnaire five minutes before conducting health education. Immediately after providing the health education, the subjects were given a posttest questionnaire with the same set of questions like that on the pretest questionnaire. Pre- and post-test results were compared to evaluate the effect of interventional health education on the participants' level of knowledge. The questionnaires were handed out and collected by trained investigators.

In addition, one month after the intervention, investigators conducted surveys involving all four primary healthcare centers to assess whether the intervention produced long-lasting effects. These surveys were designed primarily to evaluate their 
Hanna Lianti, Novi Kurnia, Kshetra Rinaldhy, Amanda Safira Aji, M. Febriadi Ismet, Rizky Amaliah | ASEAN Journal of Community Engagement | Volume 4, Number 1, 2020

knowledge and behavior regarding BA, and specifically for community health workers, whether they continued to educate others about BA. Investigators also conducted surveys concerning the use of the SCC, to assess whether it was simple and easy to use. The survey was conducted using a qualitative questionnaire that was distributed randomly and involved healthcare providers and community healthcare workers from all four healthcare centers.

\subsection{Survey instrument}

The questionnaire used in this study was developed by the investigators. The questionnaire consisted of 12 true or false questions that tested the level of participants' knowledge regarding BA and included general knowledge, symptoms, diagnosis, and management. Each item was given a score of one. Questions provided to healthcare providers and laypersons differed regarding language and level of difficulty.

Of the 12 questions on the healthcare provider's questionnaire, question numbers 1 to 3 were about neonatal jaundice in general, question numbers 4 to 6 were about pathological neonatal jaundice and BA, question numbers 7-9 were about the symptoms of BA, and finally, question numbers 10-12 were about the management and complications of BA.

There was a slight difference between the questionnaires for healthcare providers and laypersons, mostly in the terminology used. In the laypersons' questionnaire, question numbers 1-3 were about neonatal jaundice in general, question numbers 4-5 were about pathological neonatal jaundice and BA, question numbers 6-8 were about the symptoms of BA, and finally, question numbers 9-12 were about the management and complications of BA.

\subsection{Statistical analysis}

Univariate analysis was performed to describe the sociodemographic characteristics of respondents, the distribution of respondents' answers to each question, and the average value of the pretest and posttest in each group. Furthermore, a bivariate analysis was performed with the Wilcoxon signed-rank test as an alternative to the paired T-test because the distribution of values in the two groups was not normal and was skewed. The significance level was set at.05, and all tests were two-sided. 


\section{Result and Discussion}

The total sample was 371 people, including 234 laypersons (community health workers, mothers, and expectant mothers) and 137 healthcare providers (doctors, nurses, and midwives). All participants agreed to participate in health education and completed our questionnaire with a $100 \%$ response rate.

As seen in Table 1, the participants in this study were almost exclusively composed of females. Only nine participants in the healthcare provider group were males and were mostly medical doctors, with a small number of nurses. The layperson group, individuals, were exclusively composed of females, from expectant mothers, new mothers, and community healthcare workers, who were mostly housewives, retired office workers. Seven persons who were listed as other occupations in the layperson group were mostly teachers and civil servants. In the healthcare provider group, those who were listed as other professions were nutritionists, administrative assistants, and sanitarians who worked in the community health center.

Table 1. Demographic Characteristics of Respondents

\begin{tabular}{cccc}
\hline & $\begin{array}{c}\text { Layperson } \\
(\mathrm{N}=234)\end{array}$ & $\begin{array}{c}\text { Healthcare } \\
\text { Provider } \\
(\mathrm{N}=137)\end{array}$ \\
\hline Gender & & & $128(6.6 \%)$ \\
Female & $234(100 \%)$ & Female & $9(93.4 \%)$ \\
Male & $0(0 \%)$ & Male & \\
Age (years $)$ & $19(8.1 \%)$ & $<30$ & $51(37.2 \%)$ \\
$<30$ & 147 & $30-50$ & $68(49.6 \%)$ \\
$30-50$ & $(62.8 \%)$ & & $18(13.1 \%)$ \\
$>50$ & $68(29.1 \%)$ & $>50$ & \\
Education & & & $0(0 \%)$ \\
Low & $39(16.7 \%)$ & Low & $2(1.5 \%)$ \\
Middle & 153 & Middle &
\end{tabular}


Hanna Lianti, Novi Kurnia, Kshetra Rinaldhy, Amanda Safira Aji, M. Febriadi Ismet, Rizky Amaliah | ASEAN Journal of Community Engagement | Volume 4, Number 1, 2020

\begin{tabular}{lclc}
\hline & $\begin{array}{c}\text { Layperson } \\
(\mathrm{N}=234)\end{array}$ & $\begin{array}{l}\text { Healthcare } \\
\text { Provider } \\
(\mathrm{N}=137)\end{array}$ \\
& $(65.4 \%)$ & & $135(98.5 \%)$ \\
High & $33(14.1 \%)$ & High & \\
Occupation & & & $38(27.8 \%)$ \\
Housewife & 215 & Doctor & \\
Employee & $7(3.0 \%)$ & Nurse & $7(5.1 \%)$ \\
Entrepreneur & $5(2.1 \%)$ & Midwife & $50(36.5 \%)$ \\
Other & $7(3.0 \%)$ & Other & $42(30.6 \%)$ \\
\hline
\end{tabular}

Source: Authors (2019)

Their profession is also reflected in their age distribution. In both groups, the highest number of participants was within the 30-50 years age range. However, more participants aged younger than 30 years old were in the healthcare provider group. In contrast, in the layperson group, the converse was true; there were more participants aged older than 50 years old.

In this study, we categorized the educational background of participants into three groups: low, middle, and high. Individuals in the low education group were those who had studied until elementary or middle school. The middle education group comprised those who had completed the compulsory nine years of education and at least graduated from high school. The high education group comprised those who had a higher education, and at least a diploma or bachelor's degree. There were two participants in the healthcare provider group who were categorized into the middle education group. These unlikely findings were traced, and it was found that these people were those who graduated from vocational schools for nursing, which is equivalent to a high school diploma. 


\subsection{Average pretest and posttest values}

The questionnaire was given a maximum score of 12 . Based on the results of the questionnaire with a scale from 0 to 12 , the mean and median values were calculated. The distribution of all values was analyzed. As the value distribution in both groups was skewed and contained multiple outliers, the median value was used instead of the mean for the statistical analysis. The median score of pretest scores of the healthcare provider group was 9 (2-12, range), and the median score of the posttest score was 10 (6-12). While in the layperson group, the median score of the pretest was $9(0-12$,$) and the$ posttest was $9(0-11)$. The median pretest values in both groups were similar. However, the distribution of values in the healthcare provider group was more skewed in favor of better scores, compared with those in the layperson group. The posttest values in the healthcare provider group increased, but the median remained the same in the layperson group. However, the distribution of values in the layperson group became more skewed toward better scores in the posttest questionnaire compared with before the educational intervention. Statistical analysis was done using the Wilcoxon signedrank test because it did not meet the criteria for a T-test. The pre- and post-test value differences in both groups were statistically significant, with $p<.05$ for both the healthcare provider group and layperson group [Figure 2].

In addition to increasing the average value, there was also an increase in the accuracy of participants' answers in various aspects, namely in general knowledge, symptoms, diagnosis, and management. The distribution of answers in both healthcare provider and layperson group is presented in Tables 2 and 3. The increase in accuracy of correct answers for each question was also statistically analyzed. 
Hanna Lianti, Novi Kurnia, Kshetra Rinaldhy, Amanda Safira Aji, M. Febriadi Ismet, Rizky Amaliah | ASEAN Journal of Community Engagement | Volume 4, Number 1, 2020
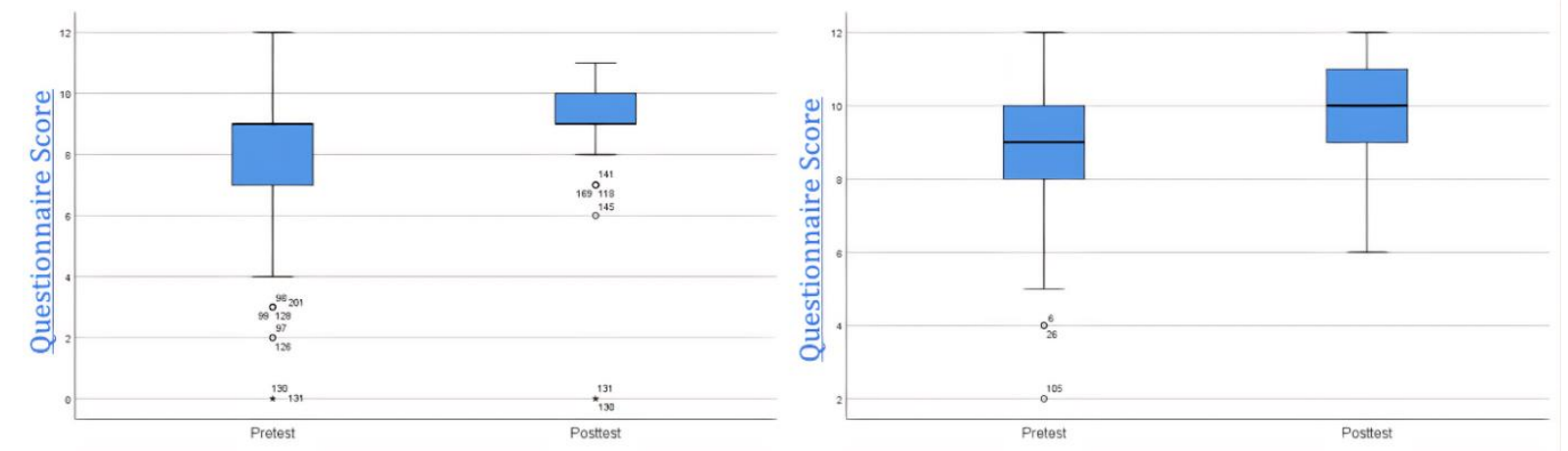

(a)
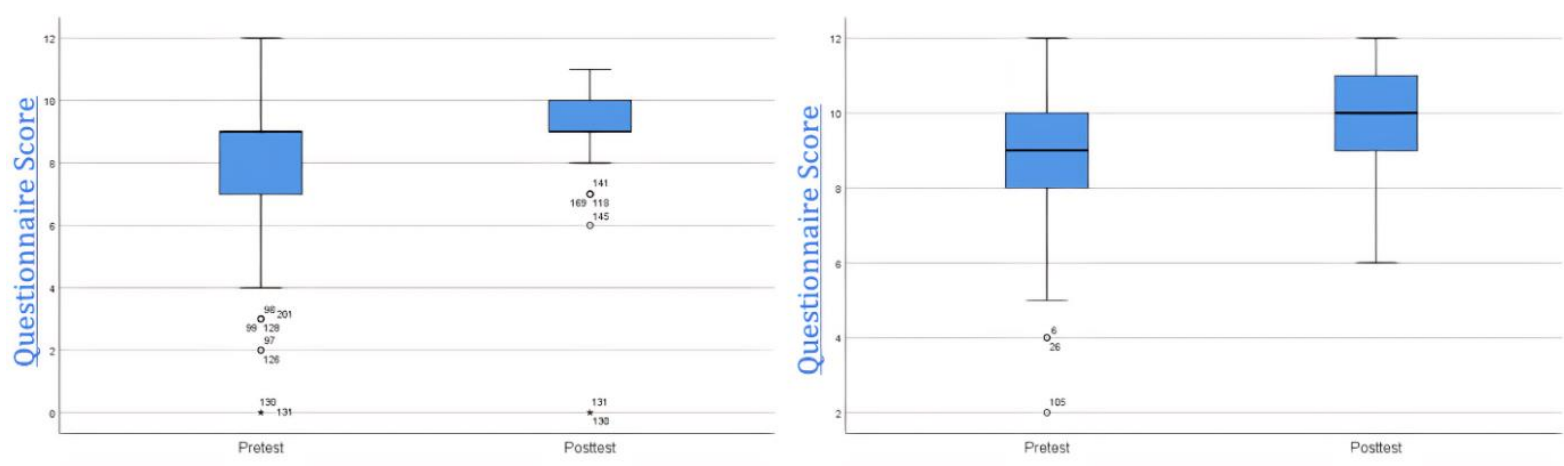

(b)

Fg. 2. Pretest and Posttest values of Healthcare Providers (a) and Laypersons (b) Source: Authors (2019)

In the healthcare provider group, there was a statistically significant increase in the number of correct answers for almost every question, except for question numbers 3 and 4. In the layperson group, one question did not have a significant increase in accuracy (question number 6), whereas another question, which conversely had a decrease in accuracy (question number 9).

For most questions, the participants in the layperson group scored higher compared with the healthcare provider, even on the pretest questionnaire. This result was because the laypersons (specifically the community healthcare workers) had received education about jaundice in babies in general on a separate occasion one month before on World Hepatitis Day. However, the increase in the number of correct answers was observably sharper in the healthcare provider group, as shown in Figure 2. In contrast, in the layperson group, the answers were more varied, with a larger number of outliers compared with the healthcare provider group. 
Hanna Lianti, Novi Kurnia, Kshetra Rinaldhy, Amanda Safira Aji, M. Febriadi Ismet, Rizky Amaliah | ASEAN Journal of Community Engagement | Volume 4, Number 1, 2020

Based on the answers from question numbers 1-3 in both groups, it can be inferred that both groups already had a prior understanding of neonatal jaundice, especially on how to recognize jaundice. However, most participants had no prior knowledge about BA. The participants from the healthcare provider group were more aware of jaundice that persisted for more than two weeks should be considered abnormal and required attention and a more thorough examination. The participants in the layperson group tended to think that jaundice would resolve by exposing their babies to sunlight. So, if jaundice persisted, it must be due to insufficient sunlight exposure. Fortunately, this belief decreased after the educational intervention, and more laypersons believed that persistent jaundice warranted further investigation.

Table 2. Distribution of Respondents' Accuracy in the Healthcare Provider Group

\begin{tabular}{|c|c|c|c|c|}
\hline \multirow{2}{*}{ No } & \multirow{2}{*}{ Questions } & \multicolumn{2}{|c|}{ Correct answer } & \multirow{2}{*}{$p$} \\
\hline & & Pretest & Posttest & \\
\hline 1. & 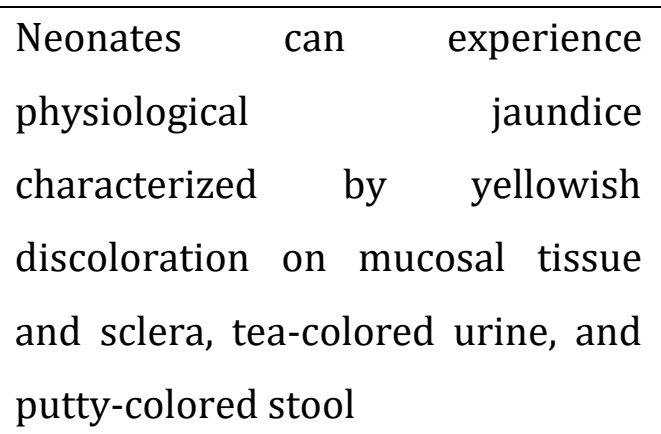 & $\begin{array}{c}63 \\
(46.0 \%)\end{array}$ & $\begin{array}{c}76 \\
(55.5 \%)\end{array}$ & $<.01$ \\
\hline 2. & $\begin{array}{l}\text { Neonatal jaundice will always } \\
\text { gradually disappear }\end{array}$ & $\begin{array}{c}50 \\
(36.5 \%)\end{array}$ & $\begin{array}{c}64 \\
(46.7 \%)\end{array}$ & .020 \\
\hline 3. & $\begin{array}{l}\text { Neonatal jaundice that does not } \\
\text { disappear after two weeks } \\
\text { indicates that the baby should be } \\
\text { examined more thoroughly, with } \\
\text { lab examinations, including serum } \\
\text { bilirubin level, gamma GT, blood } \\
\text { type, G6PD }\end{array}$ & $\begin{array}{c}89 \\
(65.0 \%)\end{array}$ & $\begin{array}{c}94 \\
(68.8 \%)\end{array}$ & .166 \\
\hline 4. & $\begin{array}{l}\text { Pathological neonatal jaundice will } \\
\text { improve by exposing the baby to } \\
\text { the morning sunlight }\end{array}$ & $\begin{array}{c}120 \\
(87.6 \%)\end{array}$ & $\begin{array}{c}124 \\
(90.5 \%)\end{array}$ & .371 \\
\hline
\end{tabular}




\begin{tabular}{|c|c|c|c|c|}
\hline \multirow{2}{*}{ No } & \multirow{2}{*}{ Questions } & \multicolumn{2}{|c|}{ Correct answer } & \multirow{2}{*}{$p$} \\
\hline & & Pretest & Posttest & \\
\hline 5. & $\begin{array}{l}\text { One cause of pathological neonatal } \\
\text { jaundice is biliary atresia }\end{array}$ & $\begin{array}{c}118 \\
(86.1 \%)\end{array}$ & $\begin{array}{c}136 \\
(99.3 \%)\end{array}$ & $<.01$ \\
\hline 6. & $\begin{array}{l}\text { The etiology of biliary atresia is } \\
\text { not clearly known yet }\end{array}$ & $\begin{array}{c}97 \\
(70.8 \%)\end{array}$ & $\begin{array}{c}116 \\
(84.7 \%)\end{array}$ & $<.01$ \\
\hline 7. & $\begin{array}{l}\text { The initial symptoms of biliary } \\
\text { atresia are that the baby looks } \\
\text { yellow, is weak and has difficulty } \\
\text { gaining weight }\end{array}$ & $\begin{array}{c}19 \\
(13.9 \%)\end{array}$ & $\begin{array}{c}51 \\
(37.2 \%)\end{array}$ & $<.01$ \\
\hline 8. & $\begin{array}{l}\text { One tool for early detection of } \\
\text { biliary atresia is the Stool Color } \\
\text { Card (SCC) }\end{array}$ & $\begin{array}{c}132 \\
(96.4 \%)\end{array}$ & $\begin{array}{c}137 \\
(100 \%)\end{array}$ & .025 \\
\hline 9. & $\begin{array}{l}\text { Stool in patients with biliary } \\
\text { atresia is pale colored like putty }\end{array}$ & $\begin{array}{c}125 \\
(91.2 \%)\end{array}$ & $\begin{array}{c}137 \\
(100 \%)\end{array}$ & $<.01$ \\
\hline 10. & $\begin{array}{l}\text { Jaundice due to biliary atresia } \\
\text { must be detected as early as } \\
\text { possible, and surgery must be } \\
\text { done before the age of } 2 \text { months }\end{array}$ & $\begin{array}{c}101 \\
(73.7 \%)\end{array}$ & $\begin{array}{c}123 \\
(89.8 \%)\end{array}$ & $<.01$ \\
\hline 11. & $\begin{array}{l}\text { Delay in management of biliary } \\
\text { atresia can cause liver cirrhosis }\end{array}$ & $\begin{array}{c}118 \\
(86.1 \%)\end{array}$ & $\begin{array}{c}129 \\
(94.2 \%)\end{array}$ & .012 \\
\hline 12. & $\begin{array}{l}\text { If biliary atresia is not treated, the } \\
\text { patient will need liver transplant } \\
\text { surgery or can end in death }\end{array}$ & $\begin{array}{c}132 \\
(96.4 \%)\end{array}$ & $\begin{array}{c}137 \\
(100 \%)\end{array}$ & .025 \\
\hline
\end{tabular}

Source: Authors (2019)

In the healthcare provider group, the accuracy of question numbers 3 and 4, did not increase significantly. Question number 3 argued that jaundice that persisted for more than two weeks should warrant further investigation. In contrast, question number 4 stated that pathological jaundice might improve or resolve only by exposing the baby to sunlight. This is due to healthcare providers' knowledge of other causes of jaundice that 
Hanna Lianti, Novi Kurnia, Kshetra Rinaldhy, Amanda Safira Aji, M. Febriadi Ismet, Rizky Amaliah | ASEAN Journal of Community Engagement | Volume 4, Number 1, 2020

they would think of first, rather than BA that may not need laboratory examinations, and might improve by exposing babies to sunlight.

Table 3. Distribution of Respondents' Accuracy in the Layperson Group

\begin{tabular}{|c|c|c|c|c|}
\hline \multirow{2}{*}{ No } & \multirow{2}{*}{ Questions } & \multicolumn{2}{|c|}{ Correct answer } & \multirow{2}{*}{$p$} \\
\hline & & Pretest & Posttest & \\
\hline 1. & $\begin{array}{l}\text { Newborns can experience } \\
\text { jaundice which is characterized } \\
\text { by yellowish discoloration on the } \\
\text { baby's skin and eyes }\end{array}$ & $\begin{array}{c}223 \\
(95.3 \%)\end{array}$ & $\begin{array}{c}230 \\
(98.3 \%)\end{array}$ & $<.001$ \\
\hline 2. & $\begin{array}{l}\text { Jaundice in babies will always } \\
\text { gradually disappear }\end{array}$ & $\begin{array}{c}27 \\
(11.5 \%)\end{array}$ & $\begin{array}{c}38 \\
(16.2 \%)\end{array}$ & .028 \\
\hline 3. & $\begin{array}{l}\text { If jaundice does not disappear } \\
\text { after } 2 \text { weeks, it means the babies } \\
\text { did not get enough sunlight } \\
\text { exposure }\end{array}$ & $\begin{array}{c}79 \\
(33.8 \%)\end{array}$ & $\begin{array}{c}117 \\
(50.0 \%)\end{array}$ & $<.001$ \\
\hline 4. & $\begin{array}{l}\text { Jaundice in babies, which is } \\
\text { caused by illness, will not } \\
\text { improve just by being exposed to } \\
\text { the sunlight }\end{array}$ & $\begin{array}{c}218 \\
(93.2 \%)\end{array}$ & $\begin{array}{c}226 \\
(96.6 \%)\end{array}$ & .046 \\
\hline 5. & $\begin{array}{l}\text { One of the diseases that causes } \\
\text { jaundice in babies is liver and bile } \\
\text { duct disease (biliary atresia) }\end{array}$ & $\begin{array}{c}209 \\
(89.3 \%)\end{array}$ & $\begin{array}{c}228 \\
(97.4 \%)\end{array}$ & $<.001$ \\
\hline 6. & $\begin{array}{l}\text { Babies with biliary atresia look } \\
\text { weak and have difficulties gaining } \\
\text { weight }\end{array}$ & $6(2.6 \%)$ & $\begin{array}{c}10 \\
(4.3 \%)\end{array}$ & .157 \\
\hline 7. & $\begin{array}{l}\text { One tool for the early detection of } \\
\text { jaundice in babies with biliary } \\
\text { atresia is the Stool Color Card } \\
\text { (SCC) }\end{array}$ & $\begin{array}{c}212 \\
(90.6 \%)\end{array}$ & $\begin{array}{c}230 \\
(98.3 \%)\end{array}$ & $<.001$ \\
\hline 8. & Stool in babies with biliary & 192 & 227 & $<.001$ \\
\hline
\end{tabular}




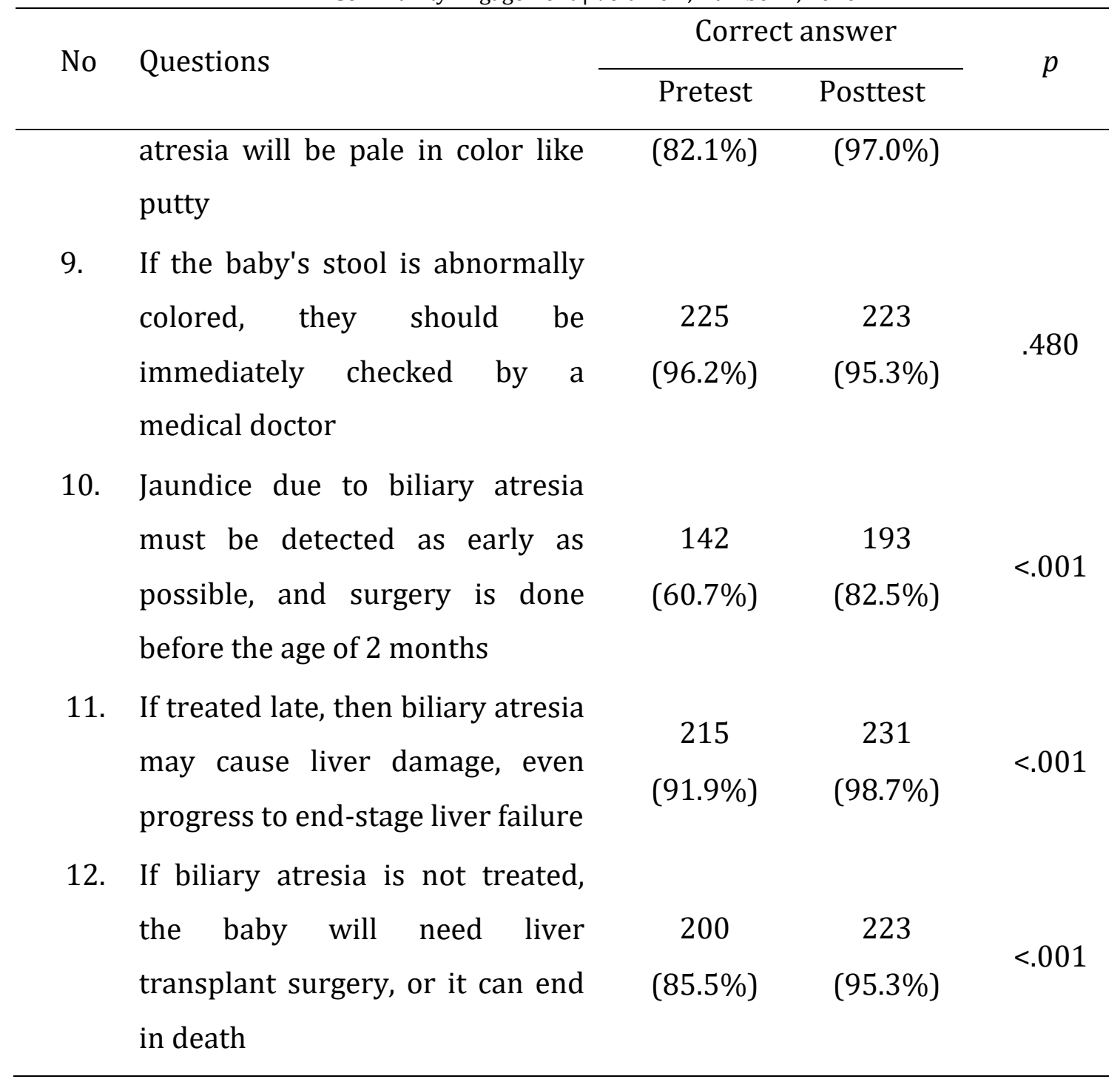

Source: Authors (2019)

Question numbers 5 and 6 in the healthcare provider group and question number 5 in the layperson group tested the knowledge of participants about BA in general. Participants in both groups claim to have heard of BA, but do not possess in-depth knowledge about the disease. The information they had on BA was limited from what they had learned from popular news forums. There were several known cases of patients with BA who had come to public attention from fundraising events for liver transplantation.

Both groups were similarly weak when tested on the topic of other symptoms of BA. For both groups, the general assumption was that babies with BA would, in addition to jaundice, look weak and have difficulties gaining weight (question number 7 in Table 2, and number 6 in Table 3). However, in reality, this is not true; babies with BA will often 
Hanna Lianti, Novi Kurnia, Kshetra Rinaldhy, Amanda Safira Aji, M. Febriadi Ismet, Rizky Amaliah | ASEAN Journal of Community Engagement | Volume 4, Number 1, 2020

have no other symptoms other than jaundice, with pale stool and dark tea-colored urine. (Oswari, 2017) Those with BA will develop other symptoms, such as an enlarged abdomen due to ascites or hematemesis when liver failure has progressed. Thus, they are in no condition to undergo the Kasai procedure. Instead, this subset of patients should be referred to prepare for liver transplantation. After health education, the number of the correct answer in the healthcare provider group significantly increased, but the overall percentage was still quite low, at 37.2\%. The numbers shown in the layperson group were even lower since only $2.6 \%$ answered correctly on the pretest, which increased to $4.3 \%$. Further re-education should be done in the future to correct this assumption. This false belief may cause jaundiced babies suspected with BA, who otherwise appear healthy, to be referred late.

Question numbers 8 and 9 in Table 2, and numbers 7 and 8 in Table 3 deal with early detection by the identification of stool color using the SCC. In both groups, participants agree that the SCC is a useful tool for early identification of BA. This belief was further supported after health education with the workshop and case simulation on how to use the SCC, as evidenced by the significantly increased number of correct answers.

Question number 9 in the layperson group discussed the timing for a more thorough examination when encountering babies with abnormally colored stool. The expected answer was that if the baby's stool is abnormally colored, the baby should be brought to seek medical attention immediately. The color of a baby's stool may not always be abnormal every time they have a bowel movement. This might cause participants to choose to wait and see if the color of the baby's next stool is indeed abnormal. It is advised to bring a child to be evaluated by qualified medical personnel immediately if the baby's stool is abnormally colored (pale, acoholic), even if it was only once. By the end of the educational intervention, $4.7 \%$ of participants still believed that a baby with abnormally colored stool did not need to be brought to be seen by a medical doctor immediately.

For the last set of questions, numbers 10 to 12 in both groups, all participants generally agreed with the statement that once BA is suspected, the patient needs to be referred to tertiary health care as soon as possible, optimally before two months of age, to be treated with the Kasai procedure to avoid permanent liver failure and the need for a liver transplant. For all three questions, the number of correct answers significantly increased in both groups. All participants understood that BA is a disease with 
Hanna Lianti, Novi Kurnia, Kshetra Rinaldhy, Amanda Safira Aji, M. Febriadi Ismet, Rizky Amaliah | ASEAN Journal of Community Engagement | Volume 4, Number 1, 2020

potentially catastrophic complications that needed to be detected and referred as early as possible.

The main aim of this study was to evaluate the effect of health education as an intervention to improve the knowledge of healthcare providers and laypersons regarding BA. In this respect, this study showed that health education significantly improved knowledge. However, to evaluate the impact of health education on improving early detection rates, we would need a long-term follow-up study, and to screen a large cohort. As an illustration, a 19-year cohort study in Japan screened a total of 313,230 live-born infants and successfully detected 34 patients with BA. (Gu et al., 2015)

Moreover, we also observed that through educational programs, the participants, especially laypersons, became empowered to be active contributors to health promotion in their communities. The community health workers continued to educate new mothers and expectant mothers on how to recognize the signs of pathological neonatal jaundice, specifically BA, using the SCC. This was done at their weekly meetings at their maternal and childcare posts throughout their respective sub-districts. This health promotion behavior persisted for even months after the conclusion of our educational interventions. In addition, most respondents also deemed the SCC as a simple and easy to use tool.

Throughout this initiative, there was coordination between the RSCM, District Health Office of East Jakarta, Primary Health Care Centers of Ciracas, Pulo Gadung, Pasar Rebo, and Kramat Jati Sub-districts and other stakeholders, to form an effective and simple referral scheme for those suspected of having BA when screened using the SCC. Further tests to exclude other differential diagnoses should be performed at the tertiary hospital level.

\section{Conclusion}

Health education interventions regarding BA has significantly increased the knowledge of healthcare providers and laypersons in primary healthcare centers about BA, as demonstrated by the significantly increased pre- and post-test values. This effective health education is expected to increase the rate of early detection and referral of patients with suspected BA when the patient's age is still in the optimum age range for Kasai surgery to avoid permanent liver damage and the need for liver 
Hanna Lianti, Novi Kurnia, Kshetra Rinaldhy, Amanda Safira Aji, M. Febriadi Ismet, Rizky Amaliah | ASEAN Journal of Community Engagement | Volume 4, Number 1, 2020

transplantation. Health education conducted during our study has also empowered laypersons. In this case, community health workers have contributed to health care by independently continuing to educate other laypersons, especially new mothers and expectant mothers, at their respective healthcare posts. These community health workers also act as an important "bridge" between other laypersons and healthcare providers.

\section{Author Contribution}

Kshetra Rinaldhy and Rizky Amaliah conceived the idea. Kshetra Rinaldhy and Rizky Amaliah developed the theory. Hanna Lianti, Amanda Safira Aji, M. Febriadi Ismet and Novi Kurnia collected data. Hanna Lianti and Amanda Safira Aji performed the statistical analysis. Kshetra Rinaldhy, Rizky Amaliah, and Novi Kurnia supervised the findings of this work. All authors discussed the results and contributed to the final manuscript.

\section{Acknowledgments}

We would like to convey our gratitude to East Jakarta District Health Office, Primary Health Care Centers of Ciracas, Pulo Gadung, Pasar Rebo, and Kramat Jati Sub-districts, and all the officers involved. The authors declare no conflict of interest.

\section{References}

Anderson, C. D., Turmelle, Y. P., Lowell, J. A., Nadler, M., Millis, M., Anand, R., ... Shepherd, R. W. (2008). The effect of recipient-specific surgical issues on outcome of liver transplantation in biliary atresia. American Journal of Transplantation, 8(6), 11971204.

https://doi.org/10.1111/j.1600-6143.2008.02223.x

Averbukh, L. D., \& Wu, G. Y. (2018). Evidence for viral induction of biliary atresia: a review. Journal of Clinical and Translational Hepatology, 6(4), 410-419. https://doi.org/10.14218/JCTH.2018.00046

Bassett, M. D., \& Murray, K. F. (2008, July). Biliary atresia: recent progress. Journal of Clinical Gastroenterology, 42(6), 720-729. 
Hanna Lianti, Novi Kurnia, Kshetra Rinaldhy, Amanda Safira Aji, M. Febriadi Ismet, Rizky Amaliah | ASEAN Journal of Community Engagement | Volume 4, Number 1, 2020

Campion, A., Guimber, D., Michaud, L., Bonnevalle, M., Turck, D., \& Gottrand, F. (2001). Analyse du retard au diagnostic de l'atrésie des voies biliaires. Archives de Pédiatrie, $8(5), 493-498$.

\section{https://doi.org/10.1016/S0929-693X(00)00251-7}

Davis, B., \& Summers, M. (2015). Applying Dale's Cone of experience to increase learning and retention: A study of student learning in a foundational leadership course. QScience Proceedings, 2015(4), 6.

https://doi.org/10.5339/qproc.2015.elc2014.6

Goodhue, C., Fenlon, M., \& Wang, K. S. (2017). Newborn screening for biliary atresia in the United States. Pediatric Surgery International, 33(12), 1315-1318.

https://doi.org/10.1007/s00383-017-4159-3

Gu, Y. H., Yokoyama, K., Mizuta, K., Tsuchioka, T., Kudo, T., Sasaki, H., ... Matsui, A. (2015). Stool color card screening for early detection of biliary atresia and longterm native liver survival: A 19-year cohort study in Japan. The Journal of Pediatrics, 166(4), 897-902.e1.

https://doi.org/10.1016/j.jpeds.2014.12.063

Hartley, J. L., Davenport, M., \& Kelly, D. A. (2009). Biliary atresia. The Lancet, 374(9702), 1704-1713.

https://doi.org/10.1016/S0140-6736(09)60946-6

Hsiao, C. H., Chang, M. H., Chen, H. L., Lee, H. C., Wu, T. C., Lin, C. C., ... Lai, M. W. (2008). Universal screening for biliary atresia using an infant stool color card in Taiwan. Hepatology, 47(4), 1233-1240.

https://doi.org/10.1002/hep.22182

Japanese Organization for International Cooperation in Family Planning. (2019).

Maternal and Child Health Handbook of Japan. Tokyo Municipal Government: Bureau of Public Health.

Kelly, D. A. (Ed.). (2017). Diseases of the Liver and Biliary System in Children. Chichester, UK: John Wiley \& Sons, Ltd. 
Hanna Lianti, Novi Kurnia, Kshetra Rinaldhy, Amanda Safira Aji, M. Febriadi Ismet, Rizky Amaliah | ASEAN Journal of Community Engagement | Volume 4, Number 1, 2020

Kong, Y.-Y., Zhao, J.-Q., Wang, J., Qiu, L., Yang, H.-H., Diao, M., ... Matsui, A. (2016).

Modified stool color card with digital images was efficient and feasible for early detection of biliary atresia-a pilot study in Beijing, China. World Journal of Pediatrics, 12(4), 415-420.

\section{https://doi.org/10.1007/s12519-016-0061-7}

Lee, M., Chen, S. C.-C., Yang, H. Y., Huang, J. H., Yeung, C. Y., \& Lee, H. C. (2016). Infant stool color card screening helps reduce the hospitalization rate and mortality of biliary atresia. Medicine, 95(12), e3166.

\section{https://doi.org/10.1097/MD.0000000000003166}

Lee, S. J., \& Reeves, T. C. (2018). Edgar Gale and the cone of experience. In R. E. West (Ed.), Foundations of Learning and Instructional Design Technology.

\section{https://lidtfoundations.pressbooks.com/}

Lien, T. H., Chang, M. H., Wu, J. F., Chen, H. L., Lee, H. C., Chen, A. C., ... Ni, Y. H. (2011). Effects of the infant stool color card screening program on 5-year outcome of biliary Atresia in Taiwan. Hepatology, 53(1), 202-208.

https://doi.org/10.1002/hep.24023

Matsui, A. (2017). Screening for biliary atresia. Pediatric Surgery International, 33(12), 1305-1313.

\section{https://doi.org/10.1007/s00383-017-4175-3}

Mogul, D., Zhou, M., Intihar, P., Schwarz, K., \& Frick, K. (2015). Cost-effective analysis of screening for biliary atresia with the stool color card. Journal of Pediatric Gastroenterology and Nutrition, 60(1), 91-98.

https://doi.org/10.1097/MPG.0000000000000569

Morinville, V., Ahmed, N., Ibberson, C., Kovacs, L., Kaczorowski, J., Bryan, S., ... Schreiber, R. (2016). Home-based screening for biliary atresia using infant stool color cards in Canada: Quebec feasibility study. Journal of Pediatric Gastroenterology and Nutrition, $62(4), 536-541$.

\section{https://doi.org/10.1097/MPG.0000000000001042}

Narasimhan, K. L., Chowdhry, S. K., Vaiphei, K., Samujh, R., Mahajan, J. K., Thapa, B. R., \& Rao, K. L. (2001). Outcome of biliary atresia from Chandigarh: results of a prospective analysis. Indian Pediatrics, 38(10), 1144-1148. 
Hanna Lianti, Novi Kurnia, Kshetra Rinaldhy, Amanda Safira Aji, M. Febriadi Ismet, Rizky Amaliah | ASEAN Journal of Community Engagement | Volume 4, Number 1, 2020

Nio, M., Sasaki, H., Wada, M., Kazama, T., Nishi, K., \& Tanaka, H. (2010). Impact of age at Kasai operation on short- and long-term outcomes of type III biliary atresia at a single institution. Journal of Pediatric Surgery, 45(12), 2361-2363.

https://doi.org/10.1016/j.jpedsurg.2010.08.032

Nio, M., Wada, M., Sasaki, H., \& Tanaka, H. (2015). Effects of age at Kasai portoenterostomy on the surgical outcome: a review of the literature. Surgery Today, 45(7), 813-818.

https://doi.org/10.1007/s00595-014-1024-Z

Oswari, H. (2017). Kuning pada Bayi Baru Lahir. Jakarta: Badan Penerbit Ikatan Dokter Anak Indonesia.

Przybylska, D., Borzęcki, A., Drop, B., Przybylski, P., \& Drop, K. (2014). Health education as an important tool in the healthcare system. Polish Journal of Public Health, 124(3), 145-147.

\section{https://doi.org/10.2478/pjph-2014-0032}

Ramachandran, P., Safwan, M., Reddy, M. S., \& Rela, M. (2015). Recent trends in the diagnosis and management of biliary atresia in developing countries. Indian Pediatrics, 52(10), 871-879.

\section{https://doi.org/10.1007/s13312-015-0735-6}

Sanchez-Valle, A. (2017). Biliary atresia: epidemiology, genetics, clinical update, and public health perspective. Advances in Pediatrics, 64(1), 285-305.

\section{https://doi.org/10.1016/j.yapd.2017.03.012}

Tseng, J. J., Lai, M. S., Lin, M. C., \& Fu, Y. C. (2011). Stool color card screening for biliary atresia. Pediatrics, 128(5), e1209-e1215.

https://doi.org/10.1542/peds.2010-3495

United Nations. (2019). World population prospects 2019. https://population.un.org/wpp/Download/Standard/Fertility/

Vizeshfar, F., Zare, M., \& Keshtkaran, Z. (2019). Role-play versus lecture methods in community health volunteers. Nurse Education Today, 79, 175-179. 
Hanna Lianti, Novi Kurnia, Kshetra Rinaldhy, Amanda Safira Aji, M. Febriadi Ismet, Rizky Amaliah | ASEAN Journal of Community Engagement | Volume 4, Number 1, 2020

Wang, K. S., Section on Surgery, Committee on Fetus and Newborn, \& Childhood Liver Disease Research Network (2015). Newborn screening for biliary atresia. Pediatrics, 136(6), e1663-e1669.

https://doi.org/10.1542/peds.2015-3570

Wildhaber, B. E. (2012). Biliary atresia: 50 years after the first Kasai. ISRN Surgery, 2012, 132089.

https://doi.org/10.5402/2012/132089

Witt, M., Lindeboom, J., Wijnja, C., Kesler, A., Keyzer-Dekker, C., Verkade, H., \& Hulscher, J. (2015). Early detection of neonatal cholestasis: inadequate assessment of stool color by parents and primary healthcare doctors. European Journal of Pediatric Surgery, 26(01), 067-073.

https://doi.org/10.1055/s-0035-1566101 